\title{
MOTIVASI PEREMPUAN MEMBUKA USAHA SEKTOR INFORMAL DI DAYA TARIK WISATA TANAH LOT, TABANAN
}

\author{
Luh Putu Aritiana Kumala Pratiwi \\ Prodi Magister Kajian Pariwisata Universitas Udayana \\ Email: aritiana.kumala.pratiwi@gmail.com
}

\begin{abstract}
The development of tourism in Tanah Lot has been able to open up opportunities for local women. The businesses that mostly cultivated by women are the selling of traditional snacks of klepon, postcards, and hairpins. Women who participate should reconsider their decision to choose a dual role, both as housewives and sellers in Tanah Lot. This article analyzes the motivation of Women in opening a business in Tanah Lot area. The results showed that the motivation of women to open a business in the informal sector in Tanah Lot, namely to be able to meet the physiological needs, safety needs, affiliations, appreciation, self-actualization, and add to work experience. The factors that affect women's motivations are internal factors such as age, educational background, family income, and marital status. While the external factors namely selling location, the condition of selling place, and having their own income.
\end{abstract}

Keywords: informal sector, women's participation, women's motivation, Tanah Lot.

\section{Pendahuluan}

Peluang usaha di Indonesia sangat dipengaruhi oleh laju pertumbuhan penduduk. Menurut hasil sensus penduduk pada tahun 2010, jumlah penduduk di Indonesia mencapai 237.556.363 orang, yang terdiri atas 119.507.580 orang laki-laki dan 118.048.783 orang perempuan (Badan Pusat Statistik, 2010). Hal ini menunjukkan bahwa jumlah perempuan setengah dari jumlah keseluruhan penduduk yang ada di Indonesia, sehingga mereka berpotensi besar untuk bekerja di berbagai sektor termasuk di ranah publik.

Terbukanya peluang usaha bagi kaum perempuan tentu akan memberikan perubahan bagi kehidupan kaum perempuan. Partisipasi perempuan dalam bidang pariwisata sangat diminati karena dipandang dapat meningkatkan perekonomian keluarganya. Bali sebagai daerah agraris sebagian besar penduduknya bekerja sebagai petani, namun seiring dengan perkembangan pariwisata penduduknya mulai bekerja di sektor pariwisata. 
Sejak awal berkembangnya, pariwisata di Bali telah dicanangkan sebagai pariwisata budaya yang dijiwai oleh agama Hindu (Ardika, 2003). Salah satu kawasan daya tarik wisata di Bali yang terkenal akan pengembangan pariwisata budaya adalah kawasan Tanah Lot. Perkembangan pariwisata di Tanah Lot dilihat dari jumlah kunjungan wisatawan yang mengalami peningkatan tiap tahunnya. Pada tahun 2010 jumlah wisatawan sebanyak 2.142.893 dan pada tahun 2014 berjumlah 3.125.205 orang. Hal ini menunjukkan bahwa dibutuhkan penyediaan fasilitas dan jasa pariwisata yang memadai guna memenuhi kebutuhan wisatawan yang nantinya dapat memberikan kontribusi pendapatan bagi masyarakat lokal.

Penyediaan fasilitas bagi wisatawan akan membuka peluang usaha bagi masyarakat lokal. Adapun peluang usaha yang diciptakan dari perkembangan pariwisata di Tanah Lot dikategorikan menjadi yaitu pedagang tetap dan tidak tetap. Pedagang tetap merupakan pedagang yang memiliki tempat berjualan menetap dan pedagang tidak tetap merupakan pedagang yang tidak memiliki tempat berjualan tetap. Data manajemen operasional Tanah Lot, menunjukkan bahwa jumlah pedagang tetap yaitu sebanyak 218 unit. Pedagang tidak tetap berjumlah 214 unit, dengan penyerapan tenaga kerja sebanyak 214 orang. Adapun usaha-usaha tidak tetap di Tanah Lot yaitu penjual postcard, penjual jepit rambut, dan penjual jajan tradisional klepon.

Dengan demikian, permasalahan yang diangkat dalam penelitian ini adalah; apakah yang memotivasi perempuan untuk membuka usaha sektor informal di kawasan Tanah Lot, dan apakah faktor-faktor yang mempengaruhi motivasi perempuan dalam membuka usaha sektor informal di kawasan daya tarik wisata Tanah Lot.

\section{Teori dan Metode}

Permasalahan tersebut dianalisis berdasarkan kajian sebelumnya yang dianggap relevan. Teori motivasi Maslow (1943) dipergunakan untuk menganalisis motivasi perempuan dalam membuka usaha sektor informal di kawasan Tanah Lot.

Artikel ini menggunakan metode deskriptif kualitatif. Informan ditentukan secara purposive, dan wawancara dilakukan hingga mendapatkan data jenuh dengan jumlah informan sebanyak 30 orang. Pengumpulan data penelitian dilakukan melalui observasi, wawancara, dan dokumentasi. Data yang sudah terkumpul dirangkum, diklasifikasikan dan dipilih berdasarkan permasalahan yang dikaji, tahapan kedua adalah penyajian data yang akan dilakukan dalam bentuk gambar, tabel, dan narasi kemudian dilanjutkan dengan tahapan ketiga penarikan kesimpulan atau disebut dengan verifikasi.

\section{Motivasi Perempuan Membuka Usaha Sektor Informal}

Dapat dikemukakan bahwa motivasi perempuan membuka usaha berbeda 
antara satu dengan yang lainnya. Dalam teori motivasi Maslow disebutkan bekerja adalah untuk memenuhi lima kebutuhan pokok yang biasa disebut dengan Teori Hirarki kebutuhan yaitu.

\subsection{Pemenuhan kebutuhan Fisiologis}

Salah satu motivasi perempuan membuka usaha sektor informal di Tanah Lot adalah untuk pemenuhan kebutuhan fisiologis atau basic needs dengan persentase sebesar 50\%. Kebutuhan fisiologis merupakan perwujudan dari kebutuhan pokok manusia yaitu sandang, pangan, papan, dan kesejahteraan individu. Kebutuhan ini merupakan kebutuhan yang amat primer, karena kebutuhan ini telah ada dan terasa sejak manusia dilahirkan. Hal ini diungkapkan sebagian besar perempuan yang membuka usaha sektor infomal di Tanah Lot. Berikut penuturan salah seorang penjual postcard Nyoman Wentri (39 Tahun) :

"Hasil saya berjualan postcard biasanya saya gunakan untuk membeli kebutuhan makan sehari-hari, jika mendapatkan lebih biasanya saya gunakan untuk membeli perabotan dapur" (Wawancara, 9 Maret 2015).

Dari penuturan Nyoman Wentri menunjukkan bahwa keinginan seorang perempuan untuk dapat membantu perekonomian keluarga sangat besar. Sebagai perempuan yang bertanggungjawab tidak akan bergantung pada suami dalam hal pemenuhan kebutuhan makan sehari-hari. Hal ini sejalan dengan pendapat Suratiyah (dalam Abdullah, 1997) yang menyatakan bahwa perempuan bekerja didorong oleh keinginan untuk memiliki uang sendiri, supaya dapat mengambil keputusan sendiri dalam menggunakan uang tanpa harus minta persetujuan dari suami. Membeli kebutuhan seharihari dengan uang yang dihasilkan sendiri memberikan peluang bagi kaum perempuan untuk mengambil keputusan sendiri apa yang akan dibelinya. Keputusan yang dilakukan oleh kaum perempuan meliputi penentuan jenis sayur atau lauk pauk yang akan dibeli, pembelian buah atau sarana upacara untuk kegiatan persembahyangan sehari-hari, membeli alat-alat mandi serta alat-alat untuk membersihkan rumah, membeli alat-alat memasak yang harganya masih terjangkau.

\subsection{Pemenuhan Kebutuhan Rasa Aman}

Kebutuhan kedua menurut Maslow yaitu kebutuhan akan rasa aman (security needs). Ketika kebutuhan fisiologis telah terpenuhi maka akan muncul kebutuhan akan keamanan. Adapun kebutuhan rasa aman yang dimaksud yaitu physical security (aman dari kejahatan dan agresi), security of employment (keselamatan kerja), security of revenues and resources (keamanan sumber daya), moral physiological security (keamanan fisiologis), familial security (keamanan keluarga), security of 
health (keamanan kesehatan), dan security of personal property against crime (keamanan kekayaan pribadi dari kejahatan).

Salah satu motivasi perempuan membuka usaha di Tanah Lot, karena kawasan ini aman dan terlindung oleh pecalang (keamanan desa adat) yang selalu melakukan patroli setiap hari nya. Selain itu, informan juga menyebutkan bahwa adanya peraturan yang harus di patuhi oleh setiap penjual yang bertujuan untuk menjaga keharmonisan antar penjual. Aturanaturan berjualan ini dibuat dan dikeluarkan oleh masing-masing organisasi usaha. Setiap organisasi di Tanah Lot mengatur standar harga untuk penjualan barang-barang anggotanya sehingga ada standar dan tidak akan ada muncul monopoli pedagang. Adanya anggota yang berjualan di Tanah Lot maka akan menimbulkan rasa aman ketika berjualan.

\subsection{Pemenuhan Kebutuhan Afiliasi}

Manusia pada hakekatnya adalah makhluk sosial yang tidak dapat memenuhi kebutuhan sendiri dan pasti memerlukan bantuan orang lain, sehingga mereka harus berinteraksi dalam memenuhi kebutuhan tersebut. Kebutuhan sosial tercermin dalam empat bentuk perasaan yaitu:

a. Kebutuhan akan perasaaan diterima orang lain dengan siapa ia bergaul dan berinteraksi di dalam organisasi sehingga akan memiliki sense of belonging yang tinggi.

b. Pada kenyataan bahwa setiap orang mempunyai jati diri yang khas dengan segala kelebihan dan kekurangannya. Dengan jati dirinya setiap manusia merasa dirinya penting, artinya ia memiliki sense of importance.

c. Kebutuhan akan perasaan maju dan tidak akan gagal sering disebut sense of accomplishment. Tidak ada orang yang merasa senang apabila ia menemui kegagalan, sebaliknya, ia senang apabila ia menemui keberhasilan.

d. Kebutuhan akan perasaan diikutsertakan (sense of participation). Kebutuhan ini sangat terasa dalam hal pengambilan keputusan yang menyangkut diri dan tugas sendiri. Bentuk dari partisipasi itu dapat beraneka ragam seperti dikonsultasikan, diminta memberikan informasi, dan didorong memberikan saran.

Kebutuhan afiliasi merupakan salah satu motivasi bagi kaum perempuan untuk membuka usaha sektor informal di Tanah Lot. Perempuan ingin menunjukan bahwa ia juga bisa bekerja dan memenuhi kebutuhan hidup seperti halnya yang dilakukan kaum laki-laki. Hal ini sejalan dengan pendapat Abdullah bahwa perempuan merasa tidak tenang jika hanya tinggal di lingkungan tempat tinggalnya, mereka lebih senang keluar rumah dan bertemu dengan teman-teman sesamanya (Abdullah, 2001). Memiliki penghasilan sendiri kaum perempuan pun dapat memenuhi kebutuhan 
tersiernya sehingga akan lebih dipandang di masyarakat ketika mampu membelinya sendiri. Kebutuhan tersier yang dimaksud adalah kebutuhan yang dipenuhi setelah kebutuhan primer dan sekunder terpenuhi. Kebutuhan tersier cenderung ke arah barang prestise di dalam masyarakat, misalnya perhiasaan emas, handphone, dan barang-barang elektronik mahal lainnya.

\subsection{Pemenuhan Kebutuhan Penghargaan}

Menurut Maslow semua manusia membutuhkan penghargaan, menghargai diri sendiri, dan juga menghargai orang lain. Orang perlu melibatkan diri untuk mendapatkan pengakuan dan mempunyai kegiatan atau kontribusi kepada orang lain dan juga nilai diri, baik di dalam pekerjaan ataupun hobi.

Terlibatnya perempuan ke ranah publik akan memungkinkan perempuan memperoleh sumber daya pribadi berupa penghasilan yang nantinya dapat merubah posisinya di dalam keluarga. Perempuan yang pada mulanya dipandang hanya bias meminta belas kasihan dari suami menjadi bergeser dan ini juga secara sosial akan merubah pandangan individu di sekitarnya. Perempuan akan dipandang lebih berarti, jika tidak bergantung sepenuhnya secara ekonomi pada suami. Keterlibatan perempuan ke dunia nafkah, tidak berarti mereka dapat melepaskan segala kewajiban pada sektor domestik dan kegiatan domestik pada dasarnya sangat mempengaruhi pengambilan keputusan perempuan untuk bekerja (Abdullah, 2001). Kondisi ini menyebabkan perempuan dalam memilih pekerjaan akan memadukan antara kerja nafkah dengan kerja rumah tangga. Menurut Hart (dikutip oleh Criss Manning, 1991:75), sektor informal sebagai bagian angkatan kerja di kota yang berada di luar pasar tenaga kerja yang terorganisasi. Sektor ini banyak dilirik oleh masyarakat yang hidup di perkotaan. Sektor informal mempunyai ciri padat karya, tingkat produktivitas rendah, tingkat pendidikan rendah, pekerja keluarga, gampang keluar masuk usaha dan merupakan usaha sendiri. Pekerja pada sektor informal kebanyakan berasal dari lapisan masyarakat bawah dan mereka hidup di kota.

Konstruksi sosial yang menempatkan perempuan dalam struktur subordinat dalam berbagai kegiatan, telah menjadi penghalang utama bagi perempuan untuk memperoleh kesempatan yang lebih baik. Wilayah perempuan yang berkisar sekitar tugas-tugas rumah tangga seringkali tidak dihargai atau dianggap tidak bernilai ekonomi. Tugas rumah tangga bagi perempuan merupakan suatu titah, perempuan adalah ratu rumah tangga (Budiman, dalam Abdullah,1997:151).

Perempuan merasa tidak tenang jika hanya tinggal di lingkungan tempat tinggalnya, mereka lebih senang keluar rumah dan bertemu dengan teman-teman seprofesi (Abdullah, 2001:143). Penghargaan masyarakat terhadap perempuan pekerja sangat tinggi. Dalam memilih pekerjaan, kaum 


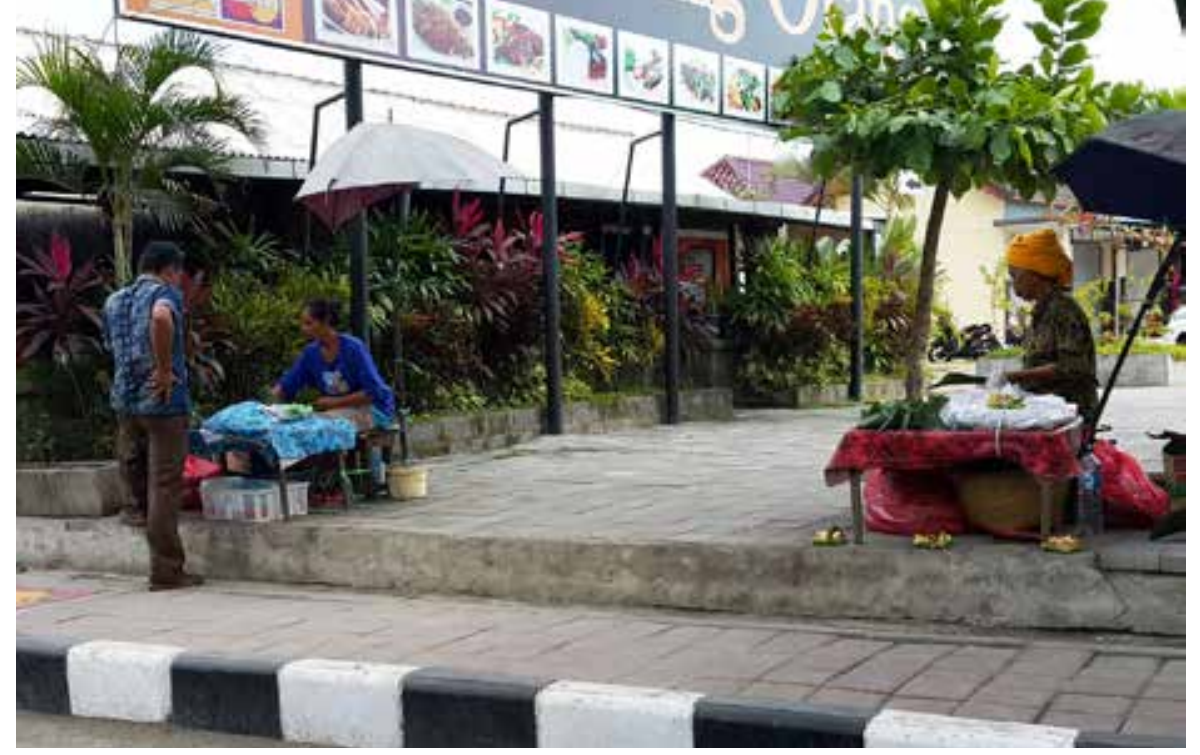

Foto 1. Perempuan penjual klepon di Tanah Lot.

perempuan juga merasa tersubordinasi oleh sistem pembagian kerja secara seksual. Pembagian kerja seksual adalah pembagian kerja yang didasarkan atasjenis kelamin. Meskipun sekarang ini banyak kaum perempuan yang berkecimpung dalam sektor publik tetapi mereka tidak bisa melepaskan diri dari beban kerja domestik, mereka boleh bekerja jika tugas-tugas rumah tangga dapat pula diselesaikan. Karena itulah, kaum perempuan dalam memilih jenis pekerjaan tidak memisahkan dirinya dari ruang keluarga atau pekerjaan yang dapat memadukan tugas reproduktif dengan tugas produktif. Salah satu jenis pekerjaan tersebut adalah berjualan di Tanah Lot yang letaknya tidak jauh dari rumah mereka. Bagi mereka berjualan dapat dilakukan setelah menyelesaikan tugas-tugas rumah tangga. Berdasarkan hasil wawancara, seluruh responden menyatakan faktor inilah yang menjadi salah satu alasan mereka untuk berjualan di Tanah Tot.

\subsection{Pemenuhan Kebutuhan Aktualisasi Diri}

Aktualisasi diri merupakan daya yang mendorong pengembangan diri dan potensi individu, sifatnya bawaan dan sudah menjadi ciri seluruh manusia. Aktualisasi diriyang mendorong manusia sampaikepada pengembanganyang optimal dan menghasilkan ciri unik manusia seperti kreativitas, inovasi. Hal ini dapat diartikan bahwa dalam diri seseorang terdapat kemampuan yang perlu dikembangkan, sehingga dapat memberikan sumbangsih yang besar terhadap kepentingan organisasi. Melalui kemampuan kerja yang semakin meningkat akan semakin mampu memuaskan berbagai kebutuhannya dan pada tingkatan ini orang cenderung untuk selalu mengembangkan diri serta berbuat yang lebih baik. Hanya 1 orang atau 3 \% yang termotivasi membuka usaha karena pemenuhan kebutuhan aktualisasi diri.

Motivasi perempuan berjualan klepon yaitu agar jajan tradisional ini dikenal oleh kalangan mancanegara. Hal ini menunjukan bahwa dari dalam 
diri perempuan ada keinginan untuk mengembangkan kemampuannya sehingga nanti akan memberikan sumbangsih kepada keberadaan jajan tradisional Bali. Berdasarkan teori Maslow kebutuhan aktualisasi diri akan muncul apabila kebutuhan-kebutuhan yang ada di bawahnya telah terpuaskan dengan baik. Kebutuhan aktualisasi ditandai sebagai hasrat individu untuk menjadi orang yang sesuai dengan keinginan dan potensi yang dimiliki, atau hasrat dari individu untuk menyempurnakan dirinya melalui pengungkapan segenap potensi yang dimilikinya.

\subsection{Mencari Pengalaman}

Bagi kaum perempuan yang belum kawin dan masih berusia muda berjualan di kawasan Tanah Lot didorong oleh keinginan untuk mencari pengalaman kerja. Dari hasil wawancara didapat bahwa terdapat 13,3 \% yang menyatakan bahwa membuka usaha di Tanah Lot termotivasi oleh untuk menambah pengalaman kerja. Pengalaman ini kelak akan lebih mudah mencari pekerjaan dibandingkan dengan tidak penah bekerja sama sekali.

Berjualan di areal pariwisata tentu akan memberikan pengalaman tersendiri bagi kaum perempuan dalam menghadapi orang asing, berkomunikasi dalam bahasa asing, memasarkan produk yang dijual dan tentunya pengalaman berorganisasi. Pengalaman ini tentu akan dapat digunakan kelak bila mereka ingin bekerja di hotel ataupun villa. Perempuan berjualan di Tanah Lot ingin menambah pengalaman berjualan yang diawali dengan usaha yang kecil terdahulu kelak berharap dapat membuka usaha yang lebih besar lagi. Berjualan di Tanah Lot mereka mendapatkan pengalaman berupa cara memasarkan barang dagangan atau produk yang dijual, menggunakan bahasa asing dalam berkomunikasi, dan cara mengelola modal sehingga tidak akan menimbulkan kerugian.

\section{Faktor yang Mempengaruhi Perempuan Membuka Usaha}

\subsection{Faktor Internal}

Faktor internal adalah faktor pendorong yang berasal dari diri perempuan yang dapat mempengaruhi motivasi perempuan dalam membuka usaha sektor informal di kawasan daya tarik wisata Tanah Lot. Herzberg dalam (Luthans, 2006) menyatakan faktor ini sebagai faktor motivator atau faktor intrinsik. Adapun variabel-variabel yang terkandung dalam faktor internal ini adalah golongan umur, tingkat pendidikan, pendapatan keluarga dan status perkawinan.

\subsubsection{Golongan Umur}

Dari golongan umur menunjukan bahwa perempuan yang membuka usaha pada sektor informal di kawasan daya tarik wisata Tanah Lot tergolong pada usia produktif untuk bekerja, yaitu antara umur 18 tahun hingga 64 
tahun. Adapun jumlah usia terendah dalam penelitian ini yaitu usia 15 20 tahun berkisar 3,3\%. Pada tingkatan usia usia 18 tahun merupakan usia perempuan yang baru menyelesaikan jenjang pendidikan pada tingkat sekolah menengah atas (SMA) dan langsung membuka usaha di Tanah Lot. Sebagian besar perempuan yang berumur 15 - 20 sedang mengenyam pendidikan di bangku sekolah ataupun kuliah. Pada jenjang usia $36-45$ merupakan usia terbanyak informan. Usia ini tergolong usia produktif perempuan untuk bekerja ataupun membuka usaha.

Faktor umur sangat berpengaruh pada motivasi perempuan membuka usaha sektor informal di kawasan daya tarik Tanah Lot. Bagi perempuan yang memiliki umur kurang dari 20 tahun menyatakan bahwa membuka pada sektor informal di kawasan daya tarik Tanah Lot untuk mengisi waktu luang sepulang kuliah, membantu usaha orangtua dan mencari pengalaman dalam berwirausaha.

Perempuan yang memiliki usia diatas 20 tahun yang sudah bisa dikatagorikan umuryang pantas untuk bekerja atau membuka usaha memiliki motivasi bekerja untuk memenuhi kebutuhan ekonomi keluarga. Perempuan pada usia produktif memiliki motivasi utama dalam bekerja adalah untuk memenuhi kebutuhan ekonomi keluarga. Sebagian besar mengaku rela bekerja walaupun penghasilan yang diperoleh rendah. membuka usaha di Tanah Lot akan mampu menambah penghasilan keluarga. Berbeda dengan perempuan yang berusia lebih dari 50 tahun yang memilih untuk tetap berjualan karena merasa jenuh jika diam saja dirumah.

Motivasi perempuan yang berusia lebih dari 50 tahun dengan membuka usaha pada sektor informal di Tanah Lot adalah untuk menghilangkan kejenuhan sehingga mencari kesibukan dengan berjualan, selain itu kebutuhan ekonomi juga menjadi alasan yang memotivasi mereka, karena mereka tidak ingin memberatkan anak dan menantu mereka.

\subsubsection{Tingkat Pendidikan}

Tingkatpendidikanmerupakan halyangsangatpenting untukmemperoleh sebuah pekerjaan saat ini, karena pendidikan sangat berpengaruh terhadap kecakapan, tingkah laku, dan sikap seseorang. Namun dalam hal ini untuk membuka usaha pada sektor informal tidak terlalu membutuhkan tingkat pendidikan yang tinggi. Sebagian besar perempuan yang membuka usaha pada sektor informal di Tanah Lot memiliki pendidikan terakhir tingkat SMA (Sekolah Menengah Atas).

Perempuan memilih membuka usaha di Tanah Lot khususnya sektor informal karena bidang ini tidaklah membutuhkan pendidikan formal yang tinggi. Hal inilah yang memotivasi perempuan untuk membuka usaha pada sektor infomal. Hanya berbekal ijazah sekolah dasar, sekolah menengah pertama atau sekolah menengah atas akan sangat susah mendapatkan 
pekerjaan lainnya, sehingga mereka memutuskan untuk berjualan di Tanah Lot. Membuka usaha di Tanah Lot dapat membantu keluarga dalam memenuhi kebutuhan sehari-hari.

\subsubsection{Pendapatan Keluarga}

Pendapatan keluarga merupakan salah satu faktor internal yang mendorong perempuan untuk membuka usaha sektor informal. Pendapatan keluarga merupakan keseluruhan hasil yang didapat oleh anggota keluarga untuk memenuhi kebutuhannya, yang dihitung dalam satuan rupiah. Semakin rendah pendapatan keluarga, maka semakin besar motivasi perempuan untuk bekerja (Siagian, 2002).

Perempuan membuka usaha karena pendapatan suaminya masih kurang untuk memenuhi kebutuhan sehari-hari. Hal inilah yang memotivasi kaum perempuan untuk membuka usaha di Tanah Lot demi kelangsungan hidup keluarganya. Perempuan membuka usaha karena ingin menyekolahkan anak yang lebih tinggi, sehingga dengan bekerja pendapatannya digunakan untuk pemenuhan kebutuhan sehari-hari dan pendapatan suami digunakan untuk pemenuhan kebutuhan sekolah anak.

\subsubsection{Status Perkawinan}

Status perkawinan mempengaruhi motivasi seseorang untuk bekerja atau membuka usaha. Dari hasil penelitian didapat bahwa 83,3\% informan sudah menikah dan $16,7 \%$ belum menikah. Hal ini menunjukkan bahwa perempuan yang sudah menikah memilik motivasi lebih dibandingkan dengan perempuan yang belum menikah. Perempuan yang sudah menikah membuka usaha karena tuntutan hidup dan ingin membantu suami dalam pemenuhan kebutuhan keluarga. Perempuan yang sudah berkeluarga terdorong untuk berjualan di Tanah Lot karena merasa sungkan kalau hanya berdiam diri dirumah. Selain itu bila sudah menikah maka kebutuhan pun akan semakin meningkat sehingga kaum perempuan hendak bekerja untuk membantu suami dalam pemenuhan kebutuhan hidup sehari-hari.

\subsection{Faktor Eksternal}

Faktor eksternal merupakan faktor yang berasal dari luar diri individu itu sendiri. Dalam penelitian ini yang dimaksud faktor eksternal adalah faktor pendorong yang berasal dari luar diri perempuan yang dapat memotivasi perempuan untuk membuka usaha sektor informal di Tanah Lot. Herzberg menyatakan faktor ini sebagai faktor higiene atau faktor ekstrinsik. Pada faktor eksternal ada beberapa variable yang digunakan yaitu lokasi tempat berjualan, kondisi tempat berjualan, dan memiliki pendapatan sendiri. 


\subsubsection{Lokasi Tempat Berjualan}

Lokasi tempat berjualan memiliki pengaruh terhadap motivasi perempuan berjualan. Lokasi yang dekat dengan rumah tentu memberikan banyak keuntungan seperti biaya transpot lebih murah, tidak perlu menyewa tempat tinggal, tidak membutuhkan banyak waktu untuk sampai di lokasi berjualan, banyak waktu yang tersisa ketika pulang berjualan.

Perempuan memilih berjualan di kawasan Tanah Lot karena mudah untuk dicapai. Lokasi berjualan yang dekat dapat memberikan waktu yang banyak bagi kaum perempuan untuk menyelesaikan pekerjaan di rumah sebelum berangkat berjualan. Banyak pekerjaan yang dapat dikerjakan sebelum berangkat berjualan seperti memasak, membersihkan rumah, sembahyang, mengantar anak sekolah, mencuci pakaian dan sebagainya.

\subsubsection{Kondisi Tempat Berjualan}

Kondisi tempat berjualan memberikan pengaruh terhadap motivasi perempuan untuk membuka usaha. Kondisi yang dimaksud adalah kondisi kekerabatan, jalinan komunikasi sesama pedagang, dan keamanan tempat berjulan. Semakin baik kondisi tempat berjualan maka motivasi perempuan untuk berjualan akan semakin tinggi, namun sebaliknya bila kondisi yang tidak baik seperti terjadi persaingan yang tidak sehat makan motivasi perempuan pun akan semakin menurun.

Kondisi tempat juga dapat diartikan area tempat berjualan, perempuan yang berjualan di Tanah Lot memiliki lokasi yang berbeda-beda tergantung jenis usaha yang dibuka. Perempuan penjual klepon terbagi menjadi dua yaitu berjualan dijalur utama masuk Tanah Lot dan jalur barat dekat Pura Batu Bolong. Perempuan penjual jepit berjualan di areal tangga masuk utama dan juga di areal Pura Enjung Galuh dan Pura Jero Kandang. Bagi perempuan penjual postcard juga memiliki tempat berjualan yang sama dengan perempuan penjual jepit. Lokasi tempat berjualan sudah di tentukan oleh organisasinya, hal ini dilakukan agar tidak terjadi perebutan lokasi antar pedagang.

\subsubsection{Memiliki Penghasilan Sendiri}

Memiliki penghasilan sendiri menjadi salah satu hal yang memotivasi perempuan berjualan sehingga dapat menambah pendapatan keluarganya. Berjualan di Jepit di Tanah Lot maka dapat membantu perekonomian keluarga sehingga tidak terlalu membebani suami dalam pemenuhan kebutuhan dapur. Perempuan merasa senang berjualan bila dapat membantu pemenuhan kesejahteraan keluarganya. Besar atau kecil penghasilan yang didapat oleh kaum perempuan akan mempengaruhi motivasi mereka dalam berjualan. 


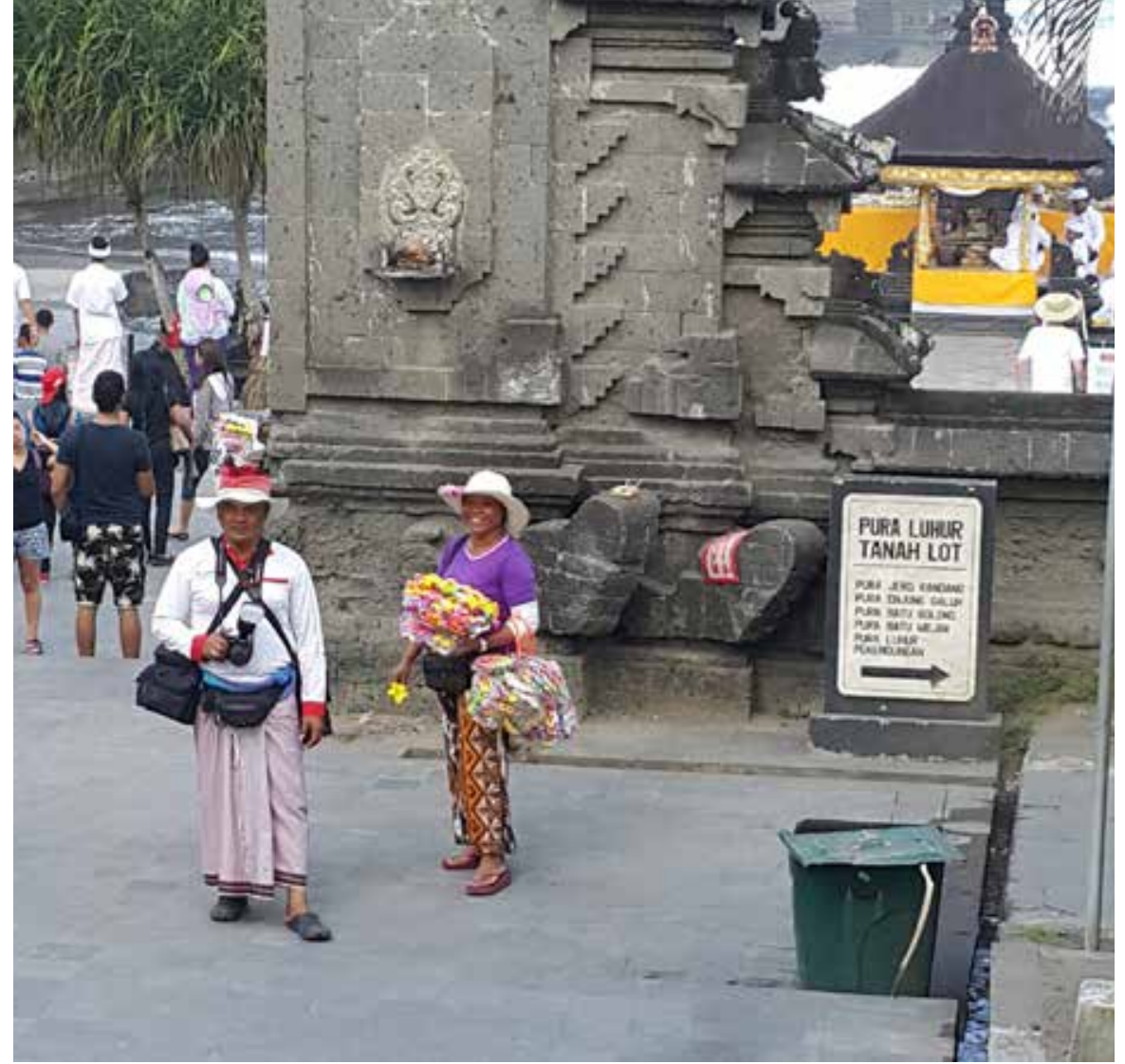

Foto 2. Interaksi perempuan penjual jepit dengan tukang foto polaroid

\section{Penutup}

Berdasarkan uraian di atas dapat disimpulkan beberapa hal berikut. Pertama, motivasi perempuan membuka usaha sektor informal di kawasan daya tarik wisata Tanah Lot yang paling banyak yaitu untuk pemenuhan kebutuhan fisiologis (50\%) dan yang paling sedikit untuk pemenuhan kebutuhan aktualisasi diri (3,3\%) hal ini dikarenakan perempuan ingin membantu keluarga dalam pemenuhan kebutuhan pokok keluarga sehingga mereka termotivasi untuk berjualan di Tanah Lot.

Kedua, adapun faktor yang mempengaruhi motivasi perempuan yaitu faktor internal dan eksternal. Faktor internal yang mempengaruhi motivasi perempuan yaitu golongan umur, tingkat pendidikan, pendapatan keluarga, dan status perkawinan. Faktor eksternal yaitu lokasi tempat berjualan, kondisi tempat berjualan, dan memiliki penghasilan sendiri. Sebagian besar perempuan termotivasi untuk membuka usaha sektor informal di Tanah Lot dikarenakan untuk pemenuhan kebutuhan fisiologis atau kebutuhan pokok.

\section{Ucapan Terima Kasih}

Penulis menyampaikan terima kasih kepada Prof. Dr. I Nyoman Darma Putra, M.Litt, selaku Ketua Program Studi Magister Kajian Pariwisata Universitas Udayana dan Dr. Ir. Syamsul Alam Paturusi, MSP., sebagai 
Sekretaris Program Studi Magister Kajian Pariwisata Universitas Udayana. Ucapan terima kasih juga ditujukan kepada Prof. Dr. I Wayan Ardika, M.A. sebagai Pembimbing I, Dr. Dewa Putu Oka Prasiasa, A.Par., M.M. selaku Pembimbing II, yang telah membimbing, mengarahkan, mendorong, dan memberikan semangat sehingga terselesainya artikel ini. Selain itu ucapan terima kasih juga disampaikan kepada para sahabat yang memberikan bantuan dan inspirasi dalam penulisan artikel ini.

\section{Daftar Pustaka}

Abdullah, I. 1997. Sangkan Peran Gender. Yogyakarta: Pustaka Pelajar dan Pusat Penelitian Kependudukan.

Abdullah, I. 2001. Seks, Gender \& Reproduksi Kekuasaan. Yogyakarta:

Tarawang Press.

Ardika, I.W. 2003. Pariwisata Budaya Berkelanjutan: Refleksi dan Harapan ditengah Perkembangan Global. Denpasar: Universitas Udayana.

Badan Pusat Statistik, 2010. Data Statistik Indonesia: Jumlah Penduduk menurut Kelompok Umur, Jenis Kelamin, Provinsi, dan Kabupaten/Kota. 2005. from:http://demografi.bps.go.id/versi1/index.php?option=com tabel\&task=\&Itemid=1. [Accessed 24 Maret 2015]

Manning, Chris., Effendi Tadjuddin Noer. 1991. Urbanisasi, Pengangguran, dan sektor Informal di Kota, Jakarta: Yayasan Obor Indonesia.

Maslow, A. 1943. A Theory of Human Motivation. Psychological Review, Vol 50: 370-396

Siagian, S.P. 2002. Kiat Meningkatkan Produktivitas Kerja. Jakarta: Asdi Mahasatya.

\section{Profil Penulis}

Luh Putu Aritiana Kumala Pratiwi, S.Par adalah mahasiswa Magister Kajian Pariwisata di Universitas Udayana Denpasar Bali. Ia menyelesaikan program S1 Destinasi Pariwisata pada tahun 2013 di Universitas Udayana. Saat ini penulis sedang bekerja di sebuah hotel pada bidang human resouces and training. 